This item was submitted to Loughborough's Research Repository by the author.

Items in Figshare are protected by copyright, with all rights reserved, unless otherwise indicated.

\title{
The Kenyan environment's influence on the emergence and development of corporate entrepreneurship among SMEs
}

PLEASE CITE THE PUBLISHED VERSION

https://www.palgrave.com/gb/book/9783319736990

PUBLISHER

Palgrave Macmillan

VERSION

AM (Accepted Manuscript)

\section{PUBLISHER STATEMENT}

This book chapter was accepted for publication in the book Dana, L-P., Ratten, V. and Honyenuga, B. (eds). African Entrepreneurship: Challenges and Opportunities for Doing Business and the definitive published version is available at http://doi.org/10.1007/978-3-319-73700-3

\section{LICENCE}

CC BY-NC-ND 4.0

\section{REPOSITORY RECORD}

Mustafa, Michael, and Mathew Hughes. 2018. "The Kenyan Environment's Influence on the Emergence and Development of Corporate Entrepreneurship Among Smes". Loughborough University.

https://hdl.handle.net/2134/26406. 


\title{
The Kenyan Environments Influence on the Emergence and Development of Corporate Entrepreneurship among SMEs
}

\author{
Michael Mustafa \\ University of Nottingham Malaysia \\ Mathew Hughes \\ Loughborough University \\ School of Business and Economics
}

\begin{abstract}
What environmental factors enable corporate entrepreneurship (CE) among African SMEs. CE helps firms to recognize and exploit new opportunities, and is particularly valuable for forms in turbulent, dynamic, or highly volatile environments of Africa. However, to date there is a dearth of research which considers the unique features of the African environmental context and their influence on the CE. To address this gap in our empirical knowledge, this study draws on Institutional Theory to examine the influence of the external environment on the emergence and development of CE among African SMEs. Given the exploratory nature of the study, a multiple case study approach was adopted. Five SMEs from Kenya's services sector formed the basis for empirical enquiry. Kenyan entrepreneurial attitudes and values along with increasing market and environmental dynamism were found to condition the emergence of CE activities among SMEs, while individual and firm-level networks and social capital, as well as deregulation of the Kenyan environment and government support initiatives were perceived as important factors that facilitate CE among SMEs. The study's findings enrich our understanding of the contingent nature of entrepreneurial activity, suggesting that African context matters. It also adds to the growing body of literature on the importance of entrepreneurship in Africa.
\end{abstract}




\section{Introduction}

Scholars have long acknowledged the significance of entrepreneurial activity due to its influence on the emergence and survival of organizations and as a driving force in economic and societal development (Bosma and Levie, 2010). The importance of entrepreneurial activity, either via the creation of new ventures or through corporate entrepreneurship (Sharma and Chrisman, 1999), is particularly significant in emerging economies. Globally, emerging economies are becoming major economic forces (Bruton et al., 2008). Particularly interesting has been the rapid rise of Africa's economies (Marzo and Patterson, 2010), which has sparked scholarly interest into how entrepreneurial activity in Africa can contribute to its development (Devine and Kiggundu, 2016).

Through the creation of new jobs and building of competitive and innovative capacity, Africa's Small-to-Medium sized (SMEs) enterprises and their entrepreneurial activities are critical components of the region's transformation (Bosma and Levie, 2010; Bruton et al., 2008). Yet, many African SMEs continue to find themselves operating in hostile environments characterized by political and macroeconomic instability, weak infrastructure, and limited access to resources (Bruton et al., 2008; Ngobo and Fouda, 2012). Such hostile environments require African SMEs to re-evaluate their traditional ways of doing business by developing entrepreneurial strategies (Hughes and Mustafa, 2016; Yiu and Lau, 2008). Corporate Entrepreneurship (CE) provides a viable strategy for SMEs to reconfigure their resources and to identify and exploit opportunities (Ireland et al., 2009) and remain competitive in Africa’s hostile environment (Tajudin et al, 2014; Yiu and Lau, 2008).

The benefits CE have been well established and empirically tested via various models that consider a range of internal, external and strategic factors (Antoncic \& Hisrich, 2001; Covin and Slevin, 1991; Guth and Ginsberg, 1990; Ireland et al., 2009). Recently, there has 
been a call to action by scholars to better understand how country and regional-level external environmental conditions influence CE (Gómez-Haro, Correa and Pozo, 2011; Hughes and Mustafa, 2016; Lim et al., 2010; Turro, Alvarez and Urbano, 2016). The external environments influence on CE is largely a perceptual phenomenon (Boyd et al., 1993). Thus, why managers a chose to engage in CE will be dependent on their perceptions of the context and the existence of specific environmental factors. However, much remains to be understood regarding how managers perceive conditions in Africa's external environment and how it influences their decisions regarding CE (de Villers-Scheeper, 2012).

Current studies examining the influence of the external environment on CE among African firms remain limited, with most focusing on a narrow set of factors based on Western-based models and assumptions (see de Villers-Scheeper, 2012; Hughes \& Mustafa, 2016). Such approaches may be problematic as they may not fully account for thw uniqueness of the African context. Therefore, further empirical work is needed to uncover external environmental factors specific to the African context, and how they influence the decisions to engage in and support CE (Hornsby et al., 2013). In light of these gaps in our knowledge, this study seeks to address the following two research questions:

RQ1: Which external environmental factors encourage African SMEs to pursue Corporate Entrepreneurship;

RQ2: Which external environmental factors influence the development of Corporate Entrepreneurship among African SMEs.

In addressing the above research questions, a qualitative investigation of five SMEs from Kenya’s service industry was utilized. As a rapidly developing African economy, Kenya is home to many SMEs (Jackson et al., 2008), which have played instrumental roles in its development (Matanda, 2012). Despite facing resource constraints, intense local and 
international competition, and cultural attitudes and institutional voids that do not favour firm-level entrepreneurship (Hughes and Mustafa, 2016), Kenyan SMEs continue remain highly entrepreneurial in nature (Jackson et al., 2008; Buil, 2017). Hence, Kenya provides an interesting context in addressing the research questions posed. The findings from this study make a valuable and timely contribution to the African entrepreneurship literature (Devine and Kiggundu, 2016)

\section{Relevant Literature}

\section{Corporate Entrepreneurship and its External Determinants}

As a strategy, Corporate Entrepreneurship (CE) enables firms to refine their business concept, address customers’ expectations and enhance their competitiveness (Zahra, 1991; Zahra and Pearce, 1994). CE is defined as the "process wherein an individual or a group of individuals, in association with an existing organization, create a new organization or instigate renewal or innovation within that organization” (Sharma and Chrisman 1999, p. 26). Broadly, CE refers to the total process wherein established organizations act in an innovative, risk-taking and proactive manner (Zahra, 1991; Dess et al., 1999). As a process, $\mathrm{CE}$ is not seen as a single event, but rather as part of the organizations culture and as a specific strategy (Ireland et al., 2009). The extent of CE within organizations vary in intensity, as it is largely dependent on changes in the organizations culture and the explorative or exploitative nature of firm activities (Sharma and Chrisman 1999).

Corporate Entrepreneurial activities in firms can come about either through strategic renewal (Altman and Zacharakis, 2003) or through corporate venturing (CV) (Guth and Ginsberg, 1990). Corporate venturing describes the various methods for creating, adding to, or investing in new businesses (Kuratko and Audretsch, 2013) that allow organizations to build their innovative capability, expand the scope of their operations and knowledge, and 
generate financial returns (Kuratko et al., 2015). CV activities may be either internal or external in nature (Narayanan et al., 2009). Strategic renewal on the other hand refers to organizational change efforts that lead to new strategy reformulation, reorganization, organizational learning and the addition of new combinations of resources resulting in competitive advantage (Zahra, 1993)

The existing literature has developed several models highlighting the main internal, environmental and strategic factors that encourage CE (Alkapan et al., 2010; Antoncic and Hisrich, 2001; Covin and Selvin, 1991; Guth and Ginsberg, 1990; Ireland et al., 2009). Specifically, manager's perceptions of the external environment, and the perceived entrepreneurial opportunities within it, can act as important stimuli for CE (Antoncic and Hisrich, 2001; Zahra, 1991). The external environment consists of macro-environmental factors such as environmental dynamism, hostility, heterogeneity and the extent of competitive rivalry in an industry (Gómez-Haro, Correa and Pozo, 2011; Turró et al., 2014; Zahra 1991). Research has shown the external environment to influence how firms formulate entrepreneurial strategies, such as self-renewal or corporate venturing strategies (Antoncic and Hisrich, 2001). Similarly, studies have also shown a relationship between the extent of legal requirements and regulatory changes (Caperlleras et al., 2008; Urbano and Turró, 2013; Zahra, 1991) and government support to significantly influence the types of CE activities (Gómez-Haro, Correa and Pozo, 2011).

In addition to economic and regulatory factors, scholars have also identified factors such as regional variations (Turro et al., 2016), cultural norms and values (Hughes and Mustafa, 2016; Turró et al., 2014; Urbano and Turró, 2013), existence of appropriate entrepreneurial role models (Urbano and Turró, 2013) and the levels of human capital and knowledge (Gómez-Haro, Correa and Pozo, 2011) within a society and influencing firm CE. 
CE can be particularly advantageous to firms in the highly turbulent and volatile markets of emerging economies wherein strategic flexibility and innovativeness is needed to maintain competitive advantages and respond to environmental pressures (Cai et al., 2014; Kantur, 2016). The environmental factors that influence CE are not universal in nature and are expected to differ between emerging economies and market-based economies (Antoncic and Hisrich, 2001; de Villers-Scheeper, 2012; Hughes and Mustafa, 2016; Yiu and Lau, 2008). Therefore, the context in which CE activities place needs to be considered (Hornsby et al., 2013; Zahra and Wright, 2011). In this particular study we consider the African context.

\section{Institutions, Africa and Corporate Entrepreneurship}

Differences in the external environmental factors s can be explained by Institutional Theory (North, 1990; Urbano and Alvarez, 2014). Institutions exert different types of pressure to which organizations respond, causing organizations to establish fields of action that define the activities of firms and the conditions under which firms obtain legitimacy (Scott, 1995). Broadly, institutions refer to the cognitive, normative, and regulative structures that provide stability and meaning to behavior (Scott 1995). Whether formal (regulations, normative, contracts, etc.) or informal (codes of conduct, attitudes, values, etc.) in nature, institutions shape decision making process concerning how CE is perceived and ultimately enacted (Gomez-Haro et al., 2011; Kantur, 2016). Hence, Western based assumptions as to how the external environment may influence CE among African firms may not be appropriate given their environmental uncertainty, lack of institutional structures and managerial interpretations of such environmental uncertainties (de Villers-Scheeper, 2012; Hughes and Mustafa, 2016).

The African external environment has often been characterized as one with significant institutional voids, environmental dynamism, and uncertainty (Devine and Kiggundu, 2016; 
George, 2015; Hoskisson et al., 2000; Zoogah et al., 2015). Such characteristics present African firms with significant organizational and developmental challenges (Ofori-Dankwa and Julian, 2013). A limited number of studies to date have examined the effects of the African external environment on CE activity. For instance, despite environmental dynamism and uncertainty found throughout Africa economies, the region's growing economies and markets are said to present firms with significant entrepreneurial opportunities (Anderson, 2011; Bosma and Levie, 2010; Bruton et al., 2008). Adomako et al. (2016) found perceptions of Ghana's economic environment by SME owners to positively attenuated the effect of their entrepreneurial orientation on their firm's performance. Similarly, de Villers-Scheeper (2012) and Madichie et al. (2013) suggested that African entrepreneurial firms still perceived attractive opportunities and increased market demand, despite an increasingly challenging operating environment. In contrast, prior findings suggest that under-developed.

Africa's external environment can also present several challenges to the development of CE among African firms. In difficult, dynamic environments such as Africa, firm entrepreneurial activity requires higher access to financial capital as well formalized procedures and legal procedures and protection (Khayesi and George, 2014; Frank, Kessler and Fink, 2010; Mambula, 2004). Yet, institutional weakness in regulatory and capital markets throughout Africa, may limit the availability of credit and private equity investment necessary to finance CV activities (Khayesi et al., 2014; Fisman, 2001). Consequently, African firms may face a proportionately greater risk of innovation failure compared to firms in developed economies and are likely to receive fewer rewards for being entrepreneurial (Sorescu and Spanjol 2008; Urban, 2012). Additionally, difficulties in acquiring financing can constrain African managers' attitudes towards innovation and their willingness to invest in CE related activities such as new product/service development or strategic renewal (Anderlini et al., 2013; Freel, 2005; Hughes and Mustafa, 2016; Obeng et al., 2014). 
Recently, empirical evidence has also emerged with regards to the effects of African culture, history, values and education on firm-level entrepreneurial activity (Zoogah et al., 2015; Spencer and Gómez, 2004). Specifically, the ability to develop an entrepreneurially minded workforce necessary for CE can be limited in Africa by the quality of human resources available and by the cultural attitudes of employees. For instance, cultural attitudes towards work and relationships among Africa employees (Jackson et al., 2008) can encourage conformity and compliance with management's instructions, thus reducing individual risk taking and creative behaviors necessary for CE to prosper. Additionally, a lack of entrepreneurial training among African employees may have implications for African firms to higher and develop an organizational culture necessary for CE (Hughes and Mustafa, 2016).

In sum, previous findings suggest that CE activity among African firms is contingent on the African institutional environment (Buli, 2017; George, 2015). Therefore, more empirical evidence is needed to understand the unique external environmental factors that influence CE among African firms. The Kenyan services industry provides an ideal context to explore the external environmental determinants of CE

\section{Kenya and Services Sector SMEs}

Kenya, with its diversified economy, has emerged as East Africa’s largest economy and a prominent player in the East Africa Community (AEC) since 2014 (Lock and LawtonSmith, 2016). Kenya’s rapid economic development has been attributed to the government's Vision 2030, which includes various efforts to increase both domestic and international competition, reduce the cost of doing business and encourage private sector innovation (Oyelaran-Oyeyinka and Sampath, 2006). 
As an important source of wealth and job creation, Kenya's many SMEs have been at the forefront its economic transformation and achieving its Vision 2030 (Matanda, 2012). Particularly, prominent have been SMEs in the Kenyan services sector. The services sector accounts for approximately 63\% of Kenya's Gross Domestic Product (GDP) and has historically led much of Kenya’s economic growth (Library of Congress 2007). As part of the nation's economic re-adjustment strategy, the sector has undergone significant social, political, economic and structural changes over the past 15 years (Nyanjom and Ong'olo, 2012). This has resulted in an opening up of the services sector to increased foreign competition, especially in the form of MNCs from the US and China (Balistreri et al., 2009). Thus, SMEs in this sector are finding themselves in a position of having to make significant adjustments to their business processes and strategies to remain competitive in the face of both domestic and international competition (Hughes and Mustafa, 2016; Jackson et al., 2008).

Despite the potential growth and development opportunities afforded by the structural changes in the service sector and Kenya in general many SMEs continue to operate in a hostile and dynamic environment characterized by limited access to financial and managerial/human capital, and increasing competition (Aulakh and Kotabe., 2000; Neshamba, 2006). However, recent empirical evidence suggests that many Kenyan SMEs continue to remain highly dynamic, innovative, and successful in such an environment (Hughes and Mustafa, 2016; Jackson et al., 2008). Therefore, an understanding of the environmental factors that condition CE in Kenyan SMEs is highly warranted.

\section{Method}

Given the paucity of research on CE in Africa, an exploratory case study approach was adopted. Recommended for studying complex and under-explored phenomena 
(Eisenhardt, 1989; Yin, 1984), the case study design permits an in-depth investigation of specific phenomena within its real-life context. Case studies are being increasingly used to examine firm-level entrepreneurial activities (Sebora et al., 2010; Zahra and Wright, 2011) and has recently been used to examine the antecedents of CE in emerging economies (Kantur and Iseri-Say 2013; Hughes and Mustafa, 2016). Therefore, the method is well-suited to understanding the external environments effect on CE in the context of African SMEs.

In this particular study, a multiple case study approach was adopted as it is generally considered as more robust than single case studies because it provides for the observation and analysis of a phenomenon in several settings (Eisenhardt, 1989, 2007; Yin, 1984). A criterion-based purposive sampling strategy was used to select five firms for empirical analysis. The following criteria were used in the identification and selection of the five case; (1) firms were from the Kenyan services sector; (2) were of small or medium-size in that they employed between 51 and 500 employees (OECD, 2004) and (3) had either initiated and implemented at least two or more CE initiatives (regarding product, service, or process innovation, or strategic renewal) within the past five years. Using information from the Kenyan Institute of Management's Company of the Year Awards database, twenty CEOs/Owners firms who met the above criteria were contacted regarding their willingness to participate in the study. After initial discussion with the CEOs/Owners, 8 agreed to further participate in the study. The final selection of cases was carried out by considering the variety of industries and markets the firms operated in and the possibility of accessing the necessary sources of information. Table 1 provides a summary of the key characteristics of the case study firms and variety of different markets and sectors of service industry they served.

INSERT TABLE 1 
Primary, data was collected using a series of semi-structured interviews with the firms' founder/CEOs and key managers over a 4-month period. All interviews were conducted in English, recorded and followed an interview protocol. Interview questions focused around what environmental factors, respondents considered as important in influencing CE in their firms. This primary data was complemented via secondary sources such as webpages, company reports, financial records, meeting minutes, brochures and observations. This enabled a deeper understanding of each case firm's history and their products as well as understanding the circumstances behind certain CE activities. The following procedure was used in analysing the data. Firstly, all interviews were coded by the author and a research assistant independently, with any inconsistencies resolved by consensus. Secondly, once the key points were coded, they were entered manually into an open-coded database. Finally, an inventory of open codes was developed around the key topics that emerged through the interviews, and categories suggested by the literature on CE and institutional theory. Also, the CE literature and Institutional Theory was utilized as they offered a terminology and conceptual references that helped to develop labels for the identified emerging factors from the data.

\section{Findings}

Drawing on case and interview evidence, along with the literature on CE and Institutional Theory, four external environmental factors specific to Kenya, which were perceived to influence the emergence and development of CE among SMEs were identified. Table 2 provide a summary of the key findings.

INSERT TABLE 2 


\section{External Environmental Factors affecting the emergence of CE}

Kenyan Entrepreneurial Attitudes and Values.

The existence of specific entrepreneurial attitudes and values among the case firm owners and senior management emerged as a significant factor in explaining why firms decided to pursue CE. Interview evidence highlighted the importance of perseverance, proactiveness, acceptance of risk, creativity and innovativeness, a strong work ethic and a desire to improve their own personal and social situation as particularly important entrepreneurial attitudes and values with respect to CE. According to respondents, such attitudes and values were also considered as important parts of Kenya's social fabric, and necessary to succeed and survive in Kenya. For instance, Firm A's founder was described as somebody who had a willingness to take considerable risk in starting a small airline company. Thus, Firm As decision to seize a larger portion of the market share by developing an online travel portal was attributed to his perseverance. As the Sales and Marketing Manager commented "Despite the few failed attempts at growing the business in a new market, he [Founder] continued to push the firm in that direct .... It's essential to have this, otherwise growth in the market may be impossible”. Similar attitudes were observed among the remainder of the case firms.

Firm B's online Sales Director came from a family with a strong entrepreneurial heritage. Since, a young age entrepreneurial values, such as being creative and innovative to overcome some of the many day-to-day and business challenges, have been drummed into him. The Sales Director drew on these values when asked by the founder to think of ways of expanding the business. Consequently, the Sales Director's solution of tying up with local banks to create an online financial service trading platform, became an instrumental means through with the firm expanded into a new niche market by creating new product offerings. Similarly, at Firm C, the CEOs individual pro-activeness and concern for Kenyan Oil \& Gas 
employees' health and well-being encouraged the firm to explore new ways to address such issues in the market. As a result, Firm $\mathrm{C}$ decided to change its business scope away from being and importer, to a custom developer of Fire and Safety equipment. As Firm Cs CEO explained "I'm always thinking of new ways of serving my community better, trying to make things better around here. They won't just get better on their own, so you have to take the initiative, think outside the box and do things better"

In sum, the abovementioned findings support previous findings that have suggested that national cultures can influence individual cognitive frameworks and hence CE activities, by affecting how individuals perceive specific issues and how they view their firms competitive landscape (Turró et al., 2014; Hughes and Mustafa, 2016; Mousa, and Wales, 2012).

Perceptions of Market and Environmental Dynamism

The evidence observed from our cases suggests that respondents' perceptions regarding the level of dynamisms found in the Kenyan environment and the opportunities contained with it, contributed to accelerating their Generally, most respondents agreed that Kenya and even Africa, was a challenging environment to operate in. As Firm Es CEO explains "there's a lot of issues and threats operating in this market [Kenya].. one has to successfully and constantly navigate them if there is any chance of survival or growth". Respondents though, were also highly cognizant of the rapid changes that had been taking place over the past 15 years in Kenyan services industry and how they influenced the entrepreneurial behaver of their firms. Specifically, changes such as an increase in competition from both abroad and locally, emergence of a new affluent middle-class and the increase use, importation of technological advancements from abroad along with government supported deregulation, while rapid and unpredictable in nature, were viewed as opening new 
entrepreneurial opportunities for case firms. As Firm B’s Marketing and Operations manager explained "yes, we face a lot of uncertainty in the market, and this has been there for a while now. But with this uncertainty, we also see a lot of new and exciting opportunities in new markets”.

Case evidence further revealed that such changes encouraged managers to adopt entrepreneurial strategies, such as moving into new market by developing new products (Firms A, B, C and D), revising existing business models and practices (Firms A, D and E) and introducing new innovations into existing markets (Firms A, B and C) to take advantage of the emergent opportunities in the Kenyan environment. For example, starting out as a small start-up company, Firm D had traditionally focussed on developing applications for Kenyan small business. However, with the growth in the size of the Kenyan economy and a subsequent expansion in government services, Firm D decided to exploit this new opportunity by developing innovative IT management solutions for several Kenyan ministries. On the other hand, declining sales and increasing competition from overseas, encouraged Firm E to seek new strategies and ways to reduce costs and increase customer engagement. As the Sales director commented, "rivalry in the market had intensified to the point that we were not competitive any longer. It was then that we decided to change internal process here, focus on de-layering, driving costs down and developing stronger relationships with our key clients". Thus, Firm E's management believed that such business transformations were necessary to remain competitive in the face of much cheaper competition from abroad.

In sum, the findings suggest that the uncertain but opportunity-rich environment of Kenya, can be important stimuli for firms to engage in CE. Such findings also support previous findings that increased dynamism in the external environment can lead to increased 
entrepreneurial postures (Antoncic and Hisrich, 2001; de Villiers-Scheepers , 2012; Mambula, 2004; Zahra, 1991).

\section{External Environmental Factors affecting the development of CE}

\section{Firm and Individual Networks and Social Capital}

Prior studies have recognized the role of networks and social capital supporting CE (Turner and Pennington, 2015; Urbano and Turró, 2013). Despite Kenya’s impressive economic growth and structural changes, numerous respondents still indicated difficulties in acquiring key resources such as financial, human capital, knowledge and technology to develop and sustain CE activities. As Firm Ds $R \& D$ manager stated " $R \& D$ projects are difficult to get off the ground. You not only need cash to get them started, but you also need to have a steady supply of it. This is the challenge in Kenya, getting regular and reliable access to such cash”. Moreover, case evidence highlighted the significance of firm social capital and individual ethnic/tribal and professional networks in the development of CE activities.

Regarding individual ethnic/tribal and professional networks, the case evidence showed that both firm founders and senior managers used such networks to acquire financial resources (A, B, C), human capital ( $A$ and D) and access key technologies (B and C) to support CE activities. For instance, to support their decision of moving into the government services industry by developing new products, Firm D created a specific operating division. However, the firm initially faced great difficulty in recruiting staff with the necessary IT skills and expertise to run and develop this division from the Kenyan labour market. To overcome this issue, Firm D’s Chief Information Officer (CIO) used his personal relationship with an MNC manager to recruit talented Software Engineers to for their new division. Similarly, Firm A's CEO leveraged on his tribal ties within the tourism ministry to bypass the bureuacratic waiting period and stringent requirements necessary in acquiring a tourism 
operator's licence. This licence, and the governmental approval and funding that came with it, helped to reduce the risk associated with designing and developing an online portal for the industry, thus further encouraging exploration with new ideas in the area. As Firm As Managing Director commented:

"Once we could secure permissions and approvals from the Ministry, we had the confidence to further explore new ideas and ways to improve our process to serve clients better".

Equally influential was the use of firm social capital. However, case evidence suggests that firm social capital was particularly important in the acquisition of high value and difficult resources or knowledge that could not be obtained easily in Kenya. For instance, over the years, Firm B had forged a long-term and special relationship with a leading Kenya financial services provider to gain in-depth knowledge regarding the financial industry. Such a relationship helped to significantly reduce the necessary investments in funding market research and helped to develop a new range of online financial services products. Similarly, several respondents also indicated the importance of acquiring the latest technologies from aboard to spur innovative activities in their firms. As the founder of Firm E stated "the latest technologies are key to our business success. In Kenya, the level of technological development is not highly sophisticated, this creates a problem for us to source our requirements locally. Hence we use our existing supplier networks to find them from overseas”. Therefore, case evidence demonstrated the beneficial nature of each of the case firms' social capital in overcoming such limitations and acquiring advanced technologies via international markets (C, D and E) and partnerships with MNCs (B and D). Acquisition of such technologies helped the firms redesign and improve existing product/service offering (B, C and E) or develop new products/services for new markets (C and D). 
Broadly, the findings above reconfirm the importance of firm and individual social capital and networks in the development and exploitation of CE activities in African SMEs, through the acquisition of specific resources to overcome the institutional constraints and inefficiencies found in Kenya (George, 2015; Khaysi et al., 2014).

\section{Perceptions of Government Regulations and Support}

Both case and interview evidence revealed that perceptions concerning government regulations and support contributed to accelerating and increasing the development of $\mathrm{CE}$ activities among the case firms. As part of its Vision 2030, the Kenyan government has engaged in a series of transformations to reform the economy. These included a deregulation of the economy and reduction in bureaucratic processes aimed at reducing the cost of doing business and encouraging private sector innovation (Oyelaran-Oyeyinka and Sampath, 2006). Generally, such initiatives were positively interpreted by respondents as it made it easier for the case firms to apply for loans (Firms A, B, C and D), operating permits (Firms A, B and E) as well as offering them with increased legal protection over innovative activities (Firms C and E). The case evidence demonstrated that such deregulation supported the development of new products/services for new markets (B, C, D and E) and encouraged significant improvements to existing products/services (A, C and D). For instance, in supporting their move into the food manufacturing industry, Firm E created a small team, charged with experimenting with new product development. Consequently, the team's success in rolling out several new innovative products, was made easier because of the ease at which they could register new ideas and the increased protection of intellectual property. As the Chief Scientist at Firm E commented:

“Compared to 10 years ago, it has become much easier to deal with the Kenyan ministries.... The time from idea to market is much much easier " 
Respondent also perceived favourably the Kenyan government's efforts to support innovation in the private sector. Several years of economic growth and political stability allowed the Kenyan government to put into place various financial and non-financial support packages to help SME increase their global and regional competitiveness. Particularly important for developing CE among the case firms were support packages such as $R \& D$ grants (Firms C and E), seed funding (Firms A and D) and tax incentives for training and development (Firm B, C and E). Case evidence suggests that such government support efforts encouraged managers to take the risks necessary to develop and put into place long-term entrepreneurial plans (B, C and D), increased their confidence in Kenya's government (A, B and C) and their willingness to take risks and commit resources for entrepreneurial activities (B, C, D and E). For instance, Firm $\mathrm{C}$ used the government funding to establish their R\&D centre, while Firms A, D and E used tax incentives to develop the entrepreneurial competencies of their employees through creativity and innovativeness training programmes. Broadly, the above findings support in part the conclusions of previous research regarding the impact of government support initiatives (Madichie et al., 2013; Mambula, 2004; Neshamba, 2006; Turró et al., 2014).

\section{Conclusions}

Given the significance of Corporate Entrepreneurship to organizational and economic development (Antoncic and Hisrich, 2001; Hoskisson et al., 2000), examining what factors contribute to enhancing its emergence and fostering its developments remain highly warranted. This may especially be the case in the context of emerging economies such Africa where there is very little theoretical and empirical knowledge concerning the phenomena CE (Madichie et al., 2013; Mambula, 2004; Ratten, 2014). Drawing on Institutional Theory to account for the influence of context, this study sought to uncover the external environmental factors that condition CE among Kenyan SMEs. Broadly, the findings from the study 
reaffirm the importance of the external environment in fostering CE (Antoncic and Hisrich, 2001; Covin and Slevin, 1991; Gómez-Haro et al., 2011). Figure 1 provides a conceptualization of the key findings. Specifically, Kenyan entrepreneurial attitudes and values along with increasing market and environmental dynamism were found to constitute important elements in the emergence of CE activities among SMEs. Additionally, individual and firm-level networks and social capital, as well as deregulation and government support initiatives were identified as important factors in facilitating CE among SMEs.

\section{INSERT FIGURE 1}

Several theoretical and managerial implications emerge from the study's findings. Theoretically, the study broadens our understanding regarding the environmental determinants of CE among African firms, a topic which has received a dearth of empirical examination by the literature (Devine and Kiggundu, 2016; Hughes and Mustafa, 2016). The prior literature has largely focused on a narrow set of external environmental factors, adopted from Western-based models (de Villers-Scheeper, 2012; Madichie et al., 2013; Obeng et al., 2014). The applicability of these factors to the African context may be questionable given the inherent environmental uncertainties, lack of institutional structures, resource availabilities and cultural attitudes found in Africa. Thus, by adopting an exploratory approach, this study uncovered a set of new external environmental determinants, specific to the Kenyan context, which influences CE. Moreover, the study's finding also provide a complimentary perspective to existing notions in the literature that the African environment largely discourages CE (Devine and Kiggundu, 2016). Instead, the study’s findings demonstrate and re-affirms the notion that corporate entrepreneurial activity may emerge and even flourish in the difficult operating environments of Africa (Devine and Kiggundu, 2016; Hughes and Mustafa, 2016; Madichie et al., 2013; Obeng et al., 2014). By doing, so the study helps to advance the literature on African entrepreneurship away from simply focusing on factors that 
lead to success and failure of African enterprises, to that of high growth and development (Benzing and Chu, 2009; Obeng et al., 2014). Additionally, the findings highlight the importance of considering the role of African contextual and cultural factors in how they influence CE (Ratten, 2014).

Regarding managerial and policy implications, the study's findings show that the despite significant challenges faced by Africa's SMEs, they can succeed with the right support. From a policy perspective, African governments could do well to lower transaction costs, reduce political and economic instabilities, and focus on developing capacity (Fosu, 2013). Such measures could be an important step in encouraging SMEs to take the risk of engaging in CE. Additionally, CE is often directly associated with the personal qualities of managers and employees (Castrogiovanni et al., 2011). Hence, policies may be needed that emphasize entrepreneurship education at both secondary and tertiary level which encourages creativity and innovativeness (van Vuuren and Botha, 2010).

\section{References}

Adomako, S., Narteh, B., Danquah, J. and Analoui, F. 2016. Entrepreneurial orientation in dynamic environments: the moderating role of extra-organizational advice. International Journal of Entrepreneurial Behavior \& Research. 22(5), pp. 616-642.

Alpkan, L., Bulut, C., Gunday, G., Ulusoy, G. and Kilic, K. 2010. Organizational support for intrapreneurship and its interaction with human capital to enhance innovative performance. Management decision 48(5), pp. 732-755.

Altman, J.W. and Zacharakis, A., 2003. An integrative model for corporate venturing. The Journal of Private Equity. 6(4), pp.68-76.

Anderson, W. 2011. Internationalization opportunities and challenges for small and mediumsized enterprises from developing countries. Journal of African Business. 12(2), pp. 198-217. 
Anderlini, L., Felli, L., Immordino, G. and Riboni, A., 2013. Legal institutions, innovation, and growth. International Economic Review. 54(3), pp.937-956.

Antoncic, B. and Hisrich, R. 2001. Intrapreneurship: Construct refinement and cross-cultural validation. Journal of Business Venturing. 16(5), pp. 495-527.

Aulakh, P.S. and Kotabe, M., 2008. Institutional changes and organizational transformation in developing economies.

Balistreri, E., Rutherford, T. and Tarr, D. 2009. Modeling services liberalization: The case of Kenya. Economic Modelling. 26(3), pp. 668-679.

Benzing, C. and Chu, H. M. 2009. A comparison of the motivations of small business owners in Africa. Journal of Small Business and Enterprise Development, 16(1), pp. 60-77.

Bosma, S. and Levie, J. 2010. Global Entrepreneurship Monitor 2009. Executive Report.

Bruton, G, Ahlstrom, D. and Obloj, K. 2008. Entrepreneurship in emerging economies: Where are we today and where should the research go in the future. Entrepreneurship Theory and \& Practice. 12(1), pp.1-14.

Boyd, B.K., Dess, G.G. and Rasheed, A.M., 1993. Divergence between archival and perceptual measures of the environment: Causes and consequences. Academy of management review. 18(2), pp.204-226.

Buli, B. M. 2017. Entrepreneurial orientation, market orientation and performance of SMEs in the manufacturing industry: evidence from Ethiopian enterprises. Management Research Review. 40(3), pp. 292-309.

Cai, L., Hughes, M. and Yin, M., 2014. The relationship between resource acquisition methods and firm performance in Chinese new ventures: the intermediate effect of learning capability. Journal of Small Business Management. 52(3), pp.365-389. 
Capelleras, J.L., Mole, K.F., Greene, F.J. and Storey, D.J., 2008. Do more heavily regulated economies have poorer performing new ventures? Evidence from Britain and Spain. Journal of International Business Studies 39(4), pp.688-704.

Castrogiovanni, G., Urbano, D. and Loras, J. 2011. Linking corporate entrepreneurship and human resource management in SMEs. International Journal of Manpower. 32(1), pp. 34-47. Covin, J.G. and Slevin, D.P. 1991. A conceptual model of entrepreneurship as firm behaviour. Entrepreneurship Theory and Practice. 16(1), pp. 7-24.

de Villiers-Scheepers, M. 2012. Antecedents of Strategic Corporate Entrepreneurship. European Business Review. 24 (5), pp. 400-424.

Dess, G., Lumpkin, G. and McKee, J. 1999. Linking corporate entrepreneurship to strategy, structure, and process: Suggested research directions. Entrepreneurship: Theory \& Practice. 23(3), pp. 85-85.

Devine, R. and Kiggundu, M. 2016. Entrepreneurship in Africa: Identifying the Frontier of Impactful Research. Africa Journal of Management. 2(3), pp. 349-380.

Eisenhardt, K. 1989. Building theories from case study research. Academy of management review. 14(4), pp. 532-550.

Fosu, A. 2013. Growth of African economies: productivity, policy syndromes and the importance of institutions. Journal of African Economies. 22(4), pp. 523-551.

George, G. 2015. Expanding context to redefine theories: Africa in management research. Management and Organization Review. 11(1), pp. 5-10.

Fisman, R., 2001. Trade credit and productive efficiency in developing countries. World Development. 29(2), pp.311-321. 
Guth, W. D. and Ginsberg, A. 1990. Guest editors' introduction: Corporate entrepreneurship. Strategic management journal. pp. 5-15.

Gomez-Haro, S., Correa, A. and Pozo, C. 2011. Differentiating the Effects of the Institutional Environment on Corporate Entrepreneurship. Management Decision. 49(9-10), pp. 16771693.

Hornsby, J., Pen a-Legazkue, I. and Guerrero, M. 2013. Guest Editorial: The Role of Corporate Entrepreneurship in the Current Organizational and Economic Land- scape. International Entrepreneurship and Management Journal. 9(3), pp. 295-305.

Hoskisson, R.E., Eden, L., Lau, C.M. and Wright, M., 2000. Strategy in emerging economies. Academy of management journal. 43(3), pp.249-267.

Hughes, M. and Mustafa, M. 2016. Antecedents of Corporate Entrepreneurship in SMEs: Evidence from an Emerging Economy. Journal of Small Business Management.

Ireland, D., Covin, J. and Kuratko, D. 2009. Conceptualizing corporate entrepreneurship strategy. Entrepreneurship theory \& practice. 33, pp. 119-46.

Jackson, T., Amaeshi, K. and Serap, Y. 2008. Untangling African Indigenous Management: Multiple Influences on the Success of SMEs in Kenya. Journal of World Business. 43(4), pp. $400-416$

Kantur, D., 2016. Strategic entrepreneurship: mediating the entrepreneurial orientationperformance link. Management Decision. 54(1), pp.24-43.

Kantur, D. and Iseri-Say, A. 2013. Organizational Context and Firm-Level Entrepreneurship: A Multiple-Case Analysis. Journal of Organizational Change Management. 26(2), pp. 305325. 
Khayesi, J. N., George, G. and Antonakis, J. 2014. Kinship in entrepreneur networks: Performance effects of resource assembly in Africa. Entrepreneurship Theory and Practice. 38(6), pp. 1323-1342.

Kuratko, D., Hornsby, J. and Hayton, J. 2015. Corporate entrepreneurship: the innovative challenge for a new global economic reality. Small Business Economics. 45(2), pp. 245-253.

Kuratko, D. and Audretsch, D. 2013. Clarifying the domains of corporate entrepreneurship. International Entrepreneurship and Management Journal. 9(3), pp. 323-335.

Lim, D.S., Morse, E.A., Mitchell, R.K. and Seawright, K.K., 2010. Institutional environment and entrepreneurial cognitions: A comparative business systems perspective. Entrepreneurship theory and Practice. 34(3), pp.491-516.

Lock, R. and Lawton Smith, H. 2016. The impact of female entrepreneurship on economic growth in Kenya. International Journal of Gender and Entrepreneurship. 8(1), pp. 90-96. Madichie, N. O., Hinson, R. E. and Ibrahim, M. 2013. A reconceptualization of entrepreneurial orientation in an emerging market insurance company. Journal of African Business. 14(3), pp. 202-214.

Mambula, C. J. 2004. A case study on the dual effect of external support and implications on small business growth, entrepreneurial creativity and performance. Journal of African business. 5(2), pp. 187-214.

Marzo, F. and Patterson, S. 2010. Africa’s outlook. OECD Observer, 279, pp. 64-65

Matanda, M. 2012. Internationalization of Established Small Manufacturers in a Developing Economy: A Case Study of Kenyan SMEs. Thunderbird International Business Review. 54(4), pp. 509-519. 
Mousa, F. and Wales, W. 2012. Founder effectiveness in leveraging entrepreneurial orientation. Management Decision. 50(2), pp. 305-324.

Narayanan, V., Yang, Y. and Zahra, S. 2009. Corporate venturing and value creation: a review and proposed framework. Research Policy. 38(1), pp. 58-76.

Neshamba, F. 2006. Why do some small businesses grow faster and become "successful" while others do not get beyond the 'foothills'? Some evidence from Kenya. Journal of African business. 7(1-2), pp. 9-30

Ngobo P. and Fouda M. 2012. Is "good” governance good for business? A cross-national analysis of firms in African countries. Journal of World Business. 47(3), pp. 435-449.

North, D.C. 1990. Institutions, institutional change and economic performance. Cambridge university press.

Nyanjom, O. and Ong'olo, D. 2012. Erratic Development in Kenya: Questions from the East Asian Miracle. Development Policy Review. 30(1), pp. 73-99

Obeng, B., Robson, P. and Haugh, H. 2014. Strategic entrepreneurship and small firm growth in Ghana. International Small Business Journal. 32(5), pp. 501-524.

Ofori-Dankwa, J. and Julian, S.D., 2013. Dynamism, capital structure, and performance in a sub-Saharan economy: Extending the institutional difference hypothesis. Organization Science. 24(5), pp.1422-1438.

Oyelaran-Oyeyinka, B. and Gehl Sampath, P. 2006. Rough road to market: institutional barriers to innovations in Africa (No. 026). United Nations University-Maastricht Economic and Social Research Institute on Innovation and Technology (MERIT). 
Ratten, V. 2014. Future research directions for collective entrepreneurship in developing countries: a small and medium-sized enterprise perspective. International Journal of Entrepreneurship and Small Business. 22(2), pp. 266-274

Scott, W. (1995). Institutions and Organizations. Thousand Oaks, CA: Sage Publications.

Sebora, T.C., Theerapatvong, T. and Lee, S.M., 2010. Corporate entrepreneurship in the face of changing competition: a case analysis of six Thai manufacturing firms. Journal of Organizational Change Management. 23(4), pp.453-470.

Sharma, P., \& Chrisman, P. 1999. Towards a Reconciliation of the Definitional Issues in the Field of Corporate Entrepreneurship. Entrepreneurship Theory \& Practice. 23(3), pp. 11-27. Spencer, J.W. and Gómez, C., 2004. The relationship among national institutional structures, economic factors, and domestic entrepreneurial activity: a multi-country study. Journal of Business Research. 57(10), pp.1098-1107.

Sorescu, A.B. and Spanjol, J., 2008. Innovation's effect on firm value and risk: Insights from consumer packaged goods. Journal of Marketing. 72(2), pp.114-132.

Tajudin, A.A., Mahmood, R.A. and Abdullah, M.H. 2014. The relationship between entrepreneurial orientation and business performance of SMEs in Malaysia. International Journal of Management Excellence. 2(3), pp. 221-236.

Turner, T. and Pennington, W. 2015. Organizational networks and the process of corporate entrepreneurship: how the motivation, opportunity, and ability to act affect firm knowledge, learning, and innovation. Small Business Economics. 45(2), 447-463.

Turro, A., Alvarez, C. and Urbano, D., 2016. Intrapreneurship in the Spanish context: a regional analysis. Entrepreneurship \& Regional Development. 28(5-6), pp.380-402. 
Turró, A., Urbano, D. and Peris-Ortiz, M. 2014. Culture and innovation: The moderating effect of cultural values on corporate entrepreneurship. Technological Forecasting and Social Change. 88, pp. 360-369.

Urban, B. 2012. The effect of pro-entrepreneurship architecture on organizational outcomes. Journal of Business Economics and Management. 13(3), pp. 518-545.

Urbano, D. and Alvarez, C., 2014. Institutional dimensions and entrepreneurial activity: An international study. Small Business Economics. 42(4), pp.703-716.

Urbano, D. and Turró, A. 2013. Conditioning factors for corporate entrepreneurship: an in (ex) ternal approach. International Entrepreneurship and Management Journal. 9(3), pp. 379-396.

van Vuuren, J. and Botha, M. 2010. The practical application of an entrepreneurial performance training model in South Africa. Journal of Small Business and Enterprise Development. 17(4), pp. 607-625.

Yin, R. 2003. Case Study Research: Design and Methods. Newbury Park, CA: Sage Yiu, D. and Lau, C. 2008. Corporate entrepreneurship as resource capital configuration in emerging market firms. Entrepreneurship Theory \& Practice. 32(1), pp. 37-57.

Zahra, S. A. and Wright, M. 2011. Entrepreneurship's next act. The Academy of Management Perspectives. 25(4), pp. 67-83.

Zahra, S.A., 1993. Environment, corporate entrepreneurship, and financial performance: A taxonomic approach. Journal of business venturing. 8(4), pp.319-340.

Zahra, S. (1991). Predictors and financial outcomes of corporate entrepreneurship: An exploratory study. Journal of business venturing. 6(4), pp. 259-285. 
Zahra, S. and Pearce, J. 1994. Corporate entrepreneurship in smaller firms: the role of environment, strategy and organization. Entrepreneurship, innovation and change. 3(1), pp. $31-44$.

Zoogah D., Peng M. and Woldu H. 2015. Institutions, resources, and organizational effectiveness in Africa. The Academy of Management Perspectives. 29, pp. 7-3. 


\begin{tabular}{|c|c|c|c|c|c|}
\hline Case & $\mathbf{A}$ & B & $\mathrm{C}$ & D & $\bar{E}$ \\
\hline Year of inception & 2004 & 1988 & 1995 & 2005 & 2003 \\
\hline $\begin{array}{l}\text { Number of CE } \\
\text { related initiatives } \\
\text { implanted since } \\
\text { inception }\end{array}$ & 4 & 7 & 3 & 3 & 4 \\
\hline Nature of Services & Tourism/Travel Services & Retail Sales (Online) & $\begin{array}{l}\text { Health and Safety Equipment } \\
\text { and Distribution Provider }\end{array}$ & Information Technology Solutions & Bio-technology \\
\hline Interviewees & $\begin{array}{l}\text { Founder, Managing } \\
\text { Director, Operations and } \\
\text { Planning Manager, Sales and } \\
\text { Marketing Manager }\end{array}$ & $\begin{array}{l}\text { Founder, Sales Director, Online } \\
\text { Projects manager, Marketing } \\
\text { and Operations Manager, } \\
\text { Employee }\end{array}$ & $\begin{array}{l}\text { CEO, Engineering Director, } \\
\text { R\&D manager, Training } \\
\text { Coordinator }\end{array}$ & $\begin{array}{l}\text { Managing Director, Chief Information Officer, } \\
\text { New Projects Manager, Software Engineer }\end{array}$ & $\begin{array}{l}\text { Founder, Sales Director, Lead Scientist, } \\
\text { Marketing and Sales Director }\end{array}$ \\
\hline $\begin{array}{l}\text { Total Number of } \\
\text { Employees }\end{array}$ & 165 & 80 & 66 & 58 & 55 \\
\hline $\begin{array}{l}\text { Annual Turnover } \\
\text { (\$USD) }\end{array}$ & $11.43 \mathrm{~m}$ & $3.1 \mathrm{~m}$ & $0.83 \mathrm{~m}$ & $2.1 \mathrm{~m}$ & $1.1 \mathrm{~m}$ \\
\hline $\begin{array}{l}\text { Business History } \\
\text { and CE Activities }\end{array}$ & $\begin{array}{l}\text { Initially started as small } \\
\text { regional airline. Rapid } \\
\text { expansion over the past } 6 \\
\text { years, with a number of } \\
\text { innovative business practices } \\
\text { developed internally. First } \\
\text { regional airline to use } \\
\text { internet bookings and } \\
\text { payment system. More } \\
\text { recent innovative activities } \\
\text { have been based around } \\
\text { developing high quality } \\
\text { products, specialized tours }\end{array}$ & $\begin{array}{l}\text { Started as a small real estate } \\
\text { firm in the late 1980's. } \\
\text { Company has grown rapidly } \\
\text { since then and branched out into } \\
\text { a number of allied areas, such } \\
\text { as property management and } \\
\text { online retailing. Recently new } \\
\text { innovative practices have } \\
\text { emerged which has enabled the } \\
\text { company to develop its own } \\
\text { online portal, and introduction } \\
\text { of financing options for } \\
\text { customers and making them the } \\
\text { premier online trading company } \\
\text { in Kenya. }\end{array}$ & $\begin{array}{l}\text { The company was mainly } \\
\text { founded from the efforts of its } \\
\text { owner, who previously was } \\
\text { working for large oil MNC in } \\
\text { Kenya. The main activity was } \\
\text { based around providing health } \\
\text { and safety equipment to oil and } \\
\text { gas companies. More recently as } \\
\text { result of CE activities, company } \\
\text { has designed their own products } \\
\text { and expanded to develop and } \\
\text { deliver their own OHS programs } \\
\text { for corporate and Oil \& Gas } \\
\text { clients. The company has also } \\
\text { moved into sales and } \\
\text { distribution of such products }\end{array}$ & $\begin{array}{l}\text { Business originally founded to provide IT } \\
\text { solutions to existing companies. Since } 2007 \text { firm } \\
\text { has engaged in a number of new projects based } \\
\text { on developing and commercializing new } \\
\text { software specifically for the East African } \\
\text { market. Original business line also expanded } \\
\text { designed to offer permanent assistance for } \\
\text { clients. Latest CE project involve rebranding } \\
\text { and change to organizational structure which } \\
\text { resulted in winning lucrative government } \\
\text { contract. }\end{array}$ & $\begin{array}{l}\text { Started as a small company selling } \\
\text { important and selling Bio-technology } \\
\text { products to medical industry. Within three } \\
\text { years, firm went through a change in } \\
\text { structure and strategy and started focusing } \\
\text { on developing custom solutions for the } \\
\text { Kenyan medical industry. In 2012, firm } \\
\text { created new division focusing on the } \\
\text { development and application of Bio-tech } \\
\text { solutions for food manufacturing industry. } \\
\text { Recent CE activity includes designing and } \\
\text { developing Bio-tech equipment for new } \\
\text { markets in Kenya and abroad }\end{array}$ \\
\hline
\end{tabular}

Table 1: Key Characteristics of Case Firms 


\begin{tabular}{|c|c|c|c|c|c|}
\hline & Case A & Case B & Case C & Case D & Case E \\
\hline $\begin{array}{l}\text { Founder and } \\
\text { Senior } \\
\text { Management } \\
\text { Team } \\
\text { Background }\end{array}$ & $\begin{array}{l}\text { Founder had prior } \\
\text { experience working } \\
\text { in tourism and } \\
\text { related industry; } \\
\text { Most of senior } \\
\text { management come } \\
\text { from start-ups or } \\
\text { tourism industry }\end{array}$ & $\begin{array}{l}\text { Founder has Masters } \\
\text { degree from abroad; Well } \\
\text { educated Senior } \\
\text { Management with strong } \\
\text { sales backgrounds and } \\
\text { experience working in } \\
\text { start-ups }\end{array}$ & $\begin{array}{l}\text { Company started as a joint } \\
\text { partnership between several people; } \\
\text { Senior management team well } \\
\text { educated and have a long history of } \\
\text { engineering experience with Oil \& } \\
\text { Gas MNCs }\end{array}$ & $\begin{array}{l}\text { Company started jointly between } \\
\text { several members of the Senior } \\
\text { Management team. Senior } \\
\text { management team highly educated } \\
\text { both locally and from aboard. Mix } \\
\text { of experience working in large } \\
\text { MNCs, international companies } \\
\text { and small new ventures }\end{array}$ & $\begin{array}{l}\text { Founder has degree in Sciences and } \\
\text { prior working experience in Bio- } \\
\text { tech industry. Senior management } \\
\text { team largely drawn from friends } \\
\text { and include individuals with } \\
\text { extensive work experience and } \\
\text { knowledge of private sector }\end{array}$ \\
\hline $\begin{array}{l}\text { Reasons for } \\
\text { starting } \\
\text { enterprise }\end{array}$ & $\begin{array}{l}\text { Desire to own } \\
\text { business and improve } \\
\text { social situation }\end{array}$ & $\begin{array}{l}\text { Wished to setup own } \\
\text { business to provide } \\
\text { support of extended } \\
\text { family }\end{array}$ & $\begin{array}{l}\text { Improve own economic and social } \\
\text { situation of workers in Oil \& Gas } \\
\text { industry }\end{array}$ & $\begin{array}{l}\text { Founding group have strong } \\
\text { cultural traditions of self- } \\
\text { employment; improve individual } \\
\text { economic situations }\end{array}$ & $\begin{array}{l}\text { Founder dis-satisfied with prior } \\
\text { working situation; wished to set up } \\
\text { own business. }\end{array}$ \\
\hline $\begin{array}{l}\text { Kenyan } \\
\text { Entrepreneurial } \\
\text { Attitudes and } \\
\text { Values }\end{array}$ & $\begin{array}{l}\text { Founder described as } \\
\text { having a persistent } \\
\text { and risk-taking } \\
\text { attitude. Senior } \\
\text { management are seen } \\
\text { as innovative and } \\
\text { proactive because of } \\
\text { their prior work } \\
\text { experiences. }\end{array}$ & $\begin{array}{l}\text { Founder has a strong } \\
\text { Christian work ethic; } \\
\text { Some members of the } \\
\text { senior management } \\
\text { described as being } \\
\text { passionate with a strong } \\
\text { entrepreneurial and } \\
\text { creative attitude }\end{array}$ & $\begin{array}{l}\text { Senior management are largely seen } \\
\text { as being proactive and willing to } \\
\text { take risks in business; Strong work } \\
\text { ethic and cultural values and } \\
\text { attitudes towards community } \\
\text { expressed. }\end{array}$ & $\begin{array}{l}\text { Management team have strong } \\
\text { cultural values towards community } \\
\text { and strong work ethics along with } \\
\text { drive and persistence. }\end{array}$ & $\begin{array}{l}\text { Founder seen as being a risk taker } \\
\text { and having a highly persistent } \\
\text { attitude; }\end{array}$ \\
\hline $\begin{array}{l}\text { Perceptions of } \\
\text { Market and } \\
\text { Environmental } \\
\text { Dynamism }\end{array}$ & $\begin{array}{l}\text { Management feel } \\
\text { that the Kenyan } \\
\text { environment filled } \\
\text { with uncertainty and } \\
\text { rapid changes. } \\
\text { Increasing rivalries } \\
\text { from local and } \\
\text { international } \\
\text { competitors along } \\
\text { with a growing } \\
\text { affluent middle class } \\
\text { encouraged firm to } \\
\text { design and develop } \\
\text { customized online } \\
\text { travel portal and } \\
\text { offer bespoke } \\
\text { adventure tours. } \\
\text { Firm revised } \\
\text { traditional business }\end{array}$ & $\begin{array}{l}\text { Management see Kenya } \\
\text { as a rapidly expanding } \\
\text { economic environment, } \\
\text { but filled with } \\
\text { uncertainty. } \\
\text { Growing middle-class } \\
\text { and desire by small } \\
\text { business for affordable } \\
\text { insurance prompted firm } \\
\text { to explore new ways of } \\
\text { offering insurance and } \\
\text { financial services } \\
\text { products. }\end{array}$ & $\begin{array}{l}\text { Management feel that Kenya is } \\
\text { experiencing significant growth, but } \\
\text { while experiencing great } \\
\text { uncertainty } \\
\text { Governments desire to create an Oil } \\
\text { \& Gas hub, lead to significant } \\
\text { reforms in the sector. Firm saw this } \\
\text { an opportunity to investment in the } \\
\text { development of new products for } \\
\text { the industry. }\end{array}$ & $\begin{array}{l}\text { Management see Kenyan } \\
\text { environment as developing for the } \\
\text { better. } \\
\text { Internally re-organized structure } \\
\text { and process to create a new } \\
\text { Government services division. Firm } \\
\text { moved away from developing apps } \\
\text { for mass consumption to design } \\
\text { and implement database solutions } \\
\text { to cater for the rapid expansion of } \\
\text { Kenyan government ministries. }\end{array}$ & $\begin{array}{l}\text { Management view Kenya as a } \\
\text { difficult operating environment; } \\
\text { Increased foreign competitors in } \\
\text { Kenya and along with growth and } \\
\text { development of local food } \\
\text { manufacturing encouraged the firm } \\
\text { to develop and implement several } \\
\text { innovations to existing process in } \\
\text { order to increase customer } \\
\text { engagement and reduce costs }\end{array}$ \\
\hline
\end{tabular}




\begin{tabular}{|c|c|c|c|c|c|}
\hline & $\begin{array}{l}\text { model by moving to } \\
\text { network based model }\end{array}$ & & & & \\
\hline $\begin{array}{l}\text { Firm and } \\
\text { Individual } \\
\text { Networks and } \\
\text { Social Capital }\end{array}$ & $\begin{array}{l}\text { Firms Director of } \\
\text { operations and } \\
\text { Managing Director } \\
\text { used their own clan } \\
\text { based relationships to } \\
\text { build a network of } \\
\text { highly reliable and } \\
\text { flexible tour } \\
\text { providers. } \\
\text { Founder utilized } \\
\text { tribal networks with } \\
\text { government to secure } \\
\text { grant funding }\end{array}$ & $\begin{array}{l}\text { Founder relied on Church } \\
\text { group network to raise } \\
\text { some capital and acquire } \\
\text { the latest server } \\
\text { technologies for the } \\
\text { development of their own } \\
\text { online sales trading } \\
\text { portal. } \\
\text { Firm utilized its strong } \\
\text { working relationship with } \\
\text { leading financial } \\
\text { company in Kenya to } \\
\text { house a developmental } \\
\text { team in their HQ. This } \\
\text { allowed the firm to gain } \\
\text { the specific and in-depth } \\
\text { knowledge about the } \\
\text { industry which was } \\
\text { instrumental in the } \\
\text { development of new } \\
\text { products for that market. }\end{array}$ & $\begin{array}{l}\text { CEO and Engineering Director used } \\
\text { personal and ethnic networks with } \\
\text { local bank managers to secure } \\
\text { short-term loans. Loans were used } \\
\text { to finance R\&D and marketing } \\
\text { efforts to build brand reputation in } \\
\text { new market } \\
\text { Firm drew on existing relationships } \\
\text { and alliances with international } \\
\text { suppliers to source and acquire 3-D } \\
\text { printing and the latest fire safety } \\
\text { technologies. Acquisition was } \\
\text { useful for the firm as it helped } \\
\text { transform the operations of firm by } \\
\text { helping them to develop their own } \\
\text { bespoke products }\end{array}$ & $\begin{array}{l}\text { Firm used personal networks of } \\
\text { senior management to identify and } \\
\text { recruit personal from MNC to staff } \\
\text { the development and management } \\
\text { of their newly created Government } \\
\text { services division } \\
\text { Firm used existing dealings with } \\
\text { both local and foreign MNCs to co- } \\
\text { develop data-base technologies. } \\
\text { Firm considered that such } \\
\text { technologies were still in their } \\
\text { infancy in Kenya and thus difficult } \\
\text { to acquire }\end{array}$ & $\begin{array}{l}\text { Firms Sales Director and Lead } \\
\text { Scientist used their own } \\
\text { relationships with past employers } \\
\text { to recruit scientists with specific } \\
\text { skills currently difficult to obtain in } \\
\text { Kenya. }\end{array}$ \\
\hline $\begin{array}{l}\text { Perceptions of } \\
\text { Government } \\
\text { Regulations and } \\
\text { Support }\end{array}$ & $\begin{array}{l}\text { Management feel } \\
\text { that government } \\
\text { changes have } \\
\text { reduced the cost of } \\
\text { doing business, and } \\
\text { increased efficiency. } \\
\text { Firm was successful } \\
\text { in securing several } \\
\text { seed funds from } \\
\text { government entities } \\
\text { to begin internal } \\
\text { transformation }\end{array}$ & $\begin{array}{l}\text { Management express } \\
\text { confidence in the long- } \\
\text { term stability and } \\
\text { economic objectives of } \\
\text { the Kenyan government } \\
\text { and its efforts to } \\
\text { deregulate } \\
\text { Firm has utilized several } \\
\text { government support } \\
\text { services, specifically } \\
\text { related to increasing the } \\
\text { productivity of the work. } \\
\text { Confidence in the }\end{array}$ & $\begin{array}{l}\text { Firm was successful in patenting } \\
\text { two of its key ideas developed by } \\
\text { the R\&D division. } \\
\text { Firms R\&D division is largely } \\
\text { sustained by several government } \\
\text { funding initiatives designed to spur } \\
\text { innovation and tax incentives. } \\
\text { Management feel optimistic about } \\
\text { the governments efforts to up-skill } \\
\text { their work-force. Management have } \\
\text { used several government back }\end{array}$ & $\begin{array}{l}\text { Management feel there is greater } \\
\text { transparency in the process of } \\
\text { dealing with government and non- } \\
\text { government institutions in Kenya. } \\
\text { Management see increase in legal } \\
\text { protection as a good sign as it } \\
\text { enabled the firms to invest more in } \\
\text { the development of costly data- } \\
\text { bases and CRM solutions. }\end{array}$ & $\begin{array}{l}\text { Increased legal protection over IP } \\
\text { and copyright laws, encouraged the } \\
\text { firm to continue to commitment } \\
\text { resources for the exploration of } \\
\text { new Bio-technology solutions for } \\
\text { the food manufacturing industry. } \\
\text { Firm was able to support the } \\
\text { purchase of new technologies from } \\
\text { government back grant. } \\
\text { Firm has used tax incentives to } \\
\text { upgrade the technical and scientific } \\
\text { skills of several of its staff. The }\end{array}$ \\
\hline
\end{tabular}




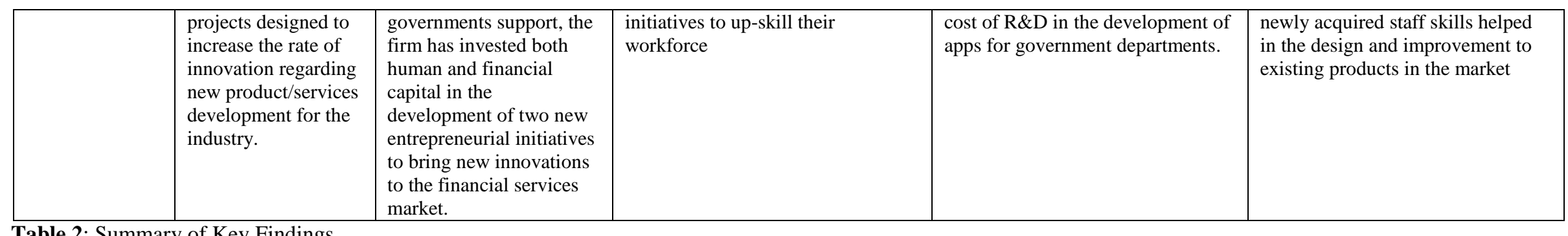

Table 2: Summary of Key Findings 


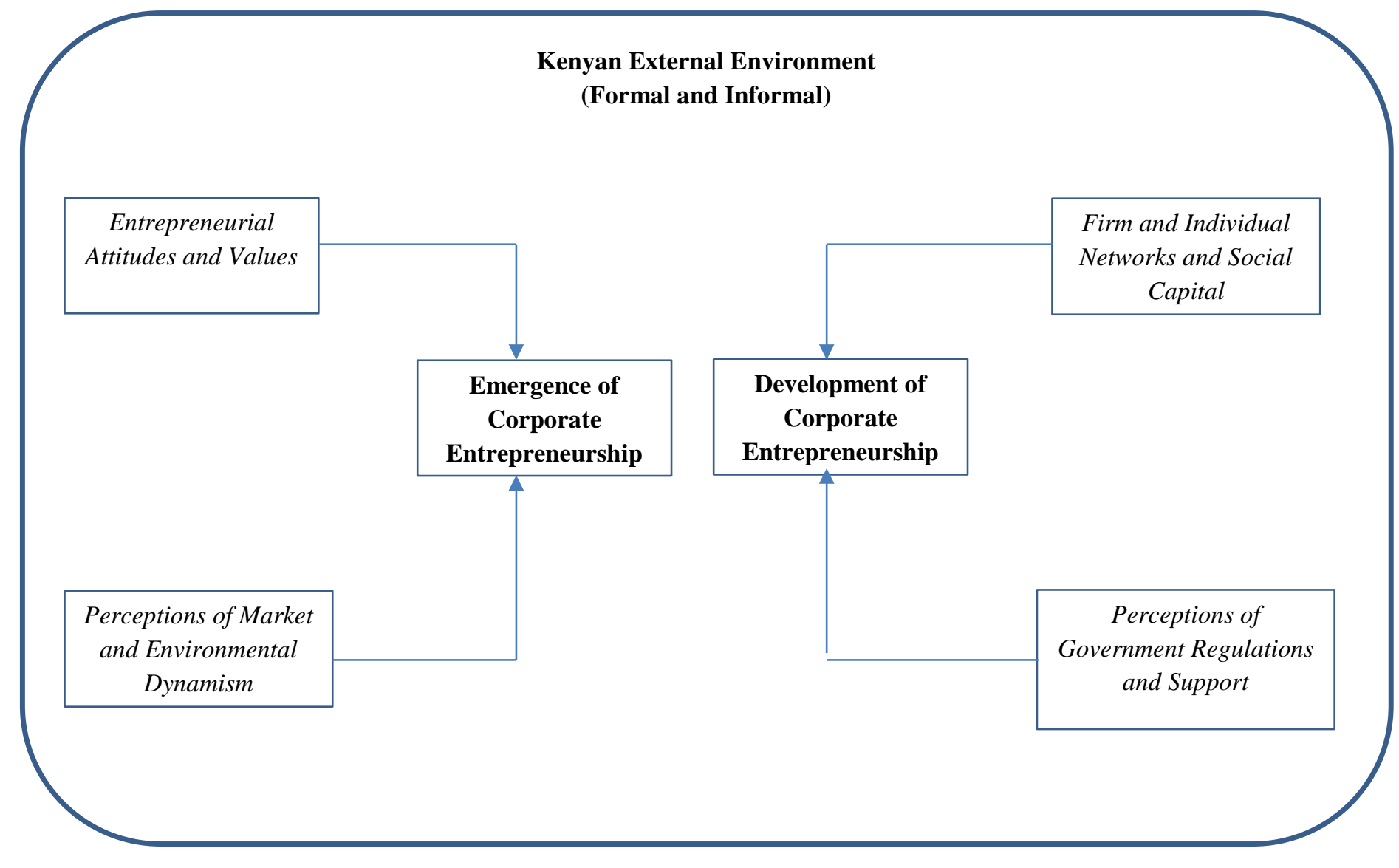

Figure 1: Conceptual Model of Key Findings 
